\title{
Effects of abamectin on lesser grain borer, Rhyzopertha dominica F. (Coleoptera: Bostrichidae), infestation on some stored grains
}

Vesna Perišić ${ }^{*}$ (B), Vladimir Perišić ${ }^{2}$, Filip Vukajlović ${ }^{3}$, Dragana Predojević ${ }^{3}$, Vera Rajičić ${ }^{1}$, Goran Andrić $^{4}$ and Petar Kljajićc

\begin{abstract}
Background: Modern methods of stored wheat grain protection from insect pests strive towards optimizing the use of different techniques and methods within integrated pest management (IPM) programs. One of the methods of integral grain protection is the application of natural originating insecticides.

Main body: The potential of the natural origin synthetic insecticide abamectin (a product of soil bacteria, Streptomyces avermitilis fermentation) on the grain borer, Rhyzopertha dominica F. (Coleoptera: Bostrichidae), in stored wheat, barley, ray, oats, and triticale was evaluated. The evaluation was conducted in 3 rates. The effects of its application on the infestation of $R$. dominica on certain physical and chemical traits of cereal grains were examined. The efficacy of abamectin after 7 days of exposure, in all applied dosages, was low $(<56.5 \%$ in wheat and $<30.5 \%$ in other grains). Abamectin efficacy was significantly increased after 14 days of exposure. $R$. dominica mortality was 99.0 and $100 \%$ after 21-day exposure at the abamectin rates of 0.5 and $1.0 \mathrm{mg} \mathrm{kg}^{-1}$, respectively. Ten weeks after grain treatment, the 3 examined rates prevented the emergence of progeny. The amount of the damaged grains and dockage, as a nus-product of feeding of $R$. dominica larvae and imago, compared to the untreated, infested sample was significantly smaller, which represents a positive aspect of abamectin application. The application did not change significantly the moisture, protein, and ash contents, in comparison to the control. Conclusion: Positive aspects of the abamectin application on different grain species (wheat, barley, rye, oats, and triticale) caused the highest rates of $R$. dominica mortality after 21 days of exposure where a total prevention of progeny emergence and absence of changes on technological grain properties occurred.
\end{abstract}

Keywords: Small grains, Rhyzopertha dominica, Abamectin, Insecticidal activity, Grain properties

\section{Background}

Wheat, besides corn, represents the most important and widespread agricultural species in Serbia. Other small grains (barley, rye, oats, and triticale) also have an important place and purpose in agricultural productionprimary in animal feeding and brewery (barley), bakery

\footnotetext{
* Correspondence: vperisic@kg.ac.rs

'Faculty of Agriculture, University of Niš, Kosančićeva 4, Kruševac 37000, Serbia

Full list of author information is available at the end of the article
}

products, and pasta production (rye and partial triticale). A common feature of different grain species is their storage possibility. In the preservation of the health and technological correctness of stored grain, temperature and air humidity of stored goods, as well as measures against diseases and pests, have crucial roles.

The lesser grain borer, Rhyzopertha dominica F. (Coleoptera: Bostrichidae), is a very dangerous and harmful primary pest that can infest all types of cereal grains. This 
pest spends most of its life cycle (larvae, pupae, and adult) in kernel and feeding on grain endosperm (Edde 2012).

Modern methods of protection of stored wheat grains from insect pests strive towards optimizing the use of different techniques and methods within integrated pest management (IPM) programs. One of the methods of integral grain protection is the application of natural originating insecticides. Abamectin is an insecticide from the group of avermectin, synthesized from natural products of fermentation of soil bacteria, Streptomyces avermitilis, having contact kill and stomach poisoning action and weak fumigation against insects and mites, with no systemic action (Kim and Goodfellow 2002).

The present research aimed to determine the efficacy of abamectin and its influence on the particular physical and chemical properties of the grain. Special attention was directed to the "grain effect" (variation in the pest sensitivity based on different grain species).

\section{Main text \\ Materials and methods \\ Experimental design}

Adults of $R$. dominica, grown on the whole wheat kernels, were used in the experiments under the laboratory conditions of $26 \pm 1{ }^{\circ} \mathrm{C}$ and $\mathrm{RH} 60 \pm 5 \%$. The age of imagoes was 2-4weeks. Five commercially available small grain varieties originating from the Center for Small Grains Kragujevac, Serbia, were used. The tested varieties of different species were wheat Vizija, barley Rekord, oats Vranac, rye Raša, and triticale Favorit. Grain samples with a moisture content ranging from 11 to $12 \%$ were used in the experiments. The moisture content was established, using the Motomco moisture meter (Motomco Inc, 919, Canada). For experimentation, the insecticidal efficacy on $R$. dominica infestation suppression in different small grain species, the natural origin insecticide Abastate EC (a.s. abamectin-18 g/l; Galenika-Fitofarmation, Serbia) was used.

The efficacy of the examined insecticide after application on small grains was determined according to the methods of evaluating the biological efficacy of insecticides in storage pest suppression (OEPP/EPPO - European and Mediterranean Plant Protection Organization 2004a, OEPP/EPPO - European and Mediterranean Plant Protection Organization 2004b). The $0.5 \mathrm{~kg}$ lots of wheat, barley, rye, oats, and triticale were weighed by an analytical balance (Mettler 609-B6, Zurich, Switzerland) and placed in glass jars of $1000 \mathrm{ml}$ volume. Abamectin aqueous solutions at the rates of $0.25,0.5$, and $1.0 \mathrm{~g}$ a.s. $\mathrm{kg}^{-1}$ of grain in the amount of $5 \mathrm{ml}$ were tested. Infested samples with $R$. dominica (untreated grains) were treated with $5 \mathrm{ml}$ of distilled water. After manually shaking of treated grains for seconds, samples were mixed on a rotary mixer for $10 \mathrm{~min}$. After that, plastic vessels $(200 \mathrm{ml}$ in volume) were filled by $50 \mathrm{~g}$ of treated, as well as untreated grain (marked as infested sample), and placed in a thermostat (XO 1450 special, Iskra, Loka, Slovenia) at the controlled conditions, $26 \pm 1{ }^{\circ} \mathrm{C}$ and $60 \pm 5 \% \mathrm{RH}$. After $24 \mathrm{~h}, 25$ adults of $R$. dominica were released (except in the control sample) into each vessel and each vessel was closed by a cotton cloth and fixed with a rubber band. Four plastic vessels were set up for every variant, i.e., 4 replications. Insect mortality was determined by sieving after 7,14 , and 21 days of exposure. Insects were completely sieved out, and samples were returned in a thermostat after 21 days of exposure. After 7 weeks in a thermostat at a constant temperature and air moisture, vessels with grains were sieved in order to determine progeny emergence and the percentage of the progeny reduction. During F1 counting, whole grain, damaged grain, and dust from each vessel were separated and weighed on an analytical scale (Mettler, Switzerland).

Intact and damaged grains as well as the dust were returned into the vessels after measurement. Additionally, samples were milled and prepared for chemical analysis of moisture, total proteins, and ash contents. Moisture content was calculated from the weight loss of the sample after drying at $130-133^{\circ} \mathrm{C}$ (International association for cereal science and technology 1976). Total nitrogen content was determined by Kjeldahl's method (International association for cereal science and technology 1994). Multiplying the corresponding results by a correction factor of 5.7 (for wheat, rye, and triticale) and 6.25 (for barley and oats), the total content of crude proteins was determined. Ash content was determined by weighing samples before and after heating in a muffle furnace at $T=900{ }^{\circ} \mathrm{C}$ for $2 \mathrm{~h}$ (International association for cereal science and technology 1990). Results were expressed as a percentage (\%) of the sample weight and presented on a dry matter basis. Untreated, uninfested samples marked (control) were used for the determination of an insecticide impact on the chemical traits of grain. For the accuracy and masked way of life of $R$. dominica, the whole procedure was repeated twice.

\section{Statistical analysis}

Recorded data were expressed as percentages of mortality and calculating standard error $(\% \pm \mathrm{SE})$. Before analysis, the percentage of mortality was transformed using arcsine, while data for the amount of insect-damaged grains and dockage were transformed by a square root. All data were processed through a one-way and multivariate analysis of variance (ANOVA and MANOVA), and the significance of differences between means was determined by the Tukey-Kramer (HSD) test (at $P=$ 
0.05 ). Pearson's coefficient (at $P=0.005$ ) was used to determine the linear correlation between the number of damaged kernels and the parameters of chemical analysis (moisture, proteins, and ash contents).

\section{Results and discussion}

The exposure period of the abamectin application significantly affected the rates of mortality $\left(F_{2,315}=\right.$ 8674.57; $P<0.01$ ) (Table 1). The influence of examined factors and their interactions on $R$. dominica among different exposure periods was statistically significant on the level of $P=0.01$. This influence was significant within a particular exposure period on the level of $P<0.01$.

The efficacy of abamectin after 7 days of exposure in all applied dosages was low. Differences in efficacy existed, especially between the highest $\left(1 \mathrm{mg} \mathrm{kg}^{-1}\right)$ and the other two $\left(0.25\right.$ and $\left.0.5 \mathrm{mg} \mathrm{kg}^{-1}\right)$. The mortality rate was significantly below $50 \%$, except in wheat at the rate of $1 \mathrm{mg} \mathrm{kg}^{-1}$ (56.5\%) (Table 2). Abamectin efficacy significantly increased after 14 days of exposure (ranged from 54.0 to $96.5 \%$ ), particularly at the highest applied rate in different grain species (85.0, 78.5, 81.0, 96.5, and $79.0 \%$, respectively). Application of $1 \mathrm{mg} \mathrm{kg}^{-1}$ in all the examined grain species contributed to significantly higher mortality rates than the other 2 applied rates, which showed significant differences in efficacy.

In samples treated with $1 \mathrm{mg} \mathrm{kg}^{-1}$ of abamectin, the highest mortality rate was recorded in oats (96.5\%), while the lowest was in triticale and barley (79.0 and $78.5 \%$, respectively). Oat samples expressed the highest mortality rate of $R$. dominica after application with 0.25 and $0.50 \mathrm{mg} \mathrm{kg}^{-1}$ ( 87.5 and $89.0 \%$, respectively), in comparison to other examined grain species, where the mortality rate was significantly lower (below 70\%). A significant difference in efficacy was not established only

Table 1 MANOVA parameters for the examined factors and their interactions of percentage of Rhyzopertha dominica mortality after abamectin application

\begin{tabular}{llll}
\hline Factors & df & $\boldsymbol{F}$ & $\boldsymbol{P}$ \\
\hline Between exposure periods & & & \\
$\quad$ Grain species & 4 & 64.37 & $<0.01$ \\
Rate & 2 & 173.04 & $<0.01$ \\
$\quad$ Grain species $\times$ rate & 8 & 7.01 & $<0.01$ \\
$\quad$ Error & 105 & & \\
Within exposure periods & & & \\
$\quad$ Exposure period & 2 & 8674.57 & $<0.01$ \\
$\quad$ Exposure period $\times$ grain species & 8 & 46.18 & $<0.01$ \\
$\quad$ Exposure period $\times$ rate & 16 & 57.20 & $<0.01$ \\
$\quad$ Exposure period $\times$ grain species $\times$ rate & 16 & 8.79 & $<0.01$ \\
Error & 210 & & \\
\hline
\end{tabular}

in rye and triticale samples at the lowest rate. The rate of $0.50 \mathrm{mg} \mathrm{kg}^{-1}$ showed a difference in efficacy between oats (the highest $89.0 \%$ ) and barley (the lowest 54.0\%), while non-significant differences in efficacy among wheat, rye, and triticale were found.

A significant increase in the abamectin efficacy, after 21 days of $R$. dominica exposure, was determined. The significance of differences in the efficacy between application of $0.5 \mathrm{mg} \mathrm{kg}^{-1}$ and $1.0 \mathrm{mg} \mathrm{kg}^{-1}$ was not established for all examined grain species. Full mortality percentage of insects $(100 \%)$ was obtained in wheat at the 3 applied rates. The mortality rate was significantly lower, at the lowest rate of $0.25 \mathrm{mg} \mathrm{kg}^{-1}$, than the rates in barley, rye, and triticale. Nevertheless, mortality rates of 99, 98.5, and 96.5\% were high too (Table 2). Nonsignificant differences in the abamectin efficacy in the examined grain species after 21 days of $R$. dominica exposure in the 3 rates were recorded (mortality > 98.5\%), except in the triticale sample treated with the lowest rate (96.5\% mortality).

The exposure period of the abamectin application, as well as other examined factors and their interactions, had significant impacts on the percentage of $R$. dominica mortality. Results pointed out an increasing abamectin efficacy with increasing applied rate and exposure period of $R$. dominica, as well as decreasing differences in efficacy among grain species (wheat, barley, rye, oats, and triticale). The recorded results are in agreement with Beeman and Speirs (1984), as one of the first researches about abamectin efficacy against $R$. dominica in stored wheat. The authors used the crystal form of avermectin B1 and concluded that the percentage of $R$. dominica mortality and progeny reduction were correlated to the applied amount of avermectin and exposure period. Kavallieratos et al. (2009) reported high mortality rates of $R$. dominica and Sitophilus oryzae in corn than in wheat and highlighted the necessity of 14-day exposure of $R$. dominica adults in wheat treated with 0.5 and $1.0 \mathrm{mg} \mathrm{kg}^{-1}$ of abamectin for the efficacy at level $>95 \%$.

Ten weeks after grain treatment, the 3 rates of examined insecticide concentrations prevented progeny emergence of the pest (Table 3). The highest progeny number was obtained in the control sample of triticale (432.50 individuals), then in rye (177.10 individuals) and wheat (128.50 individuals), while oats had the lowest suitability for the pest development (36.40 individuals).

The insecticidal effect on progeny emergence of harmful pests is a very important parameter for making decisions about the long protecting potential in stored grains (Subramanyam and Roesli 2000; Athanassiou and Kavallieratos 2005). The 3 rates of examined insecticide prevented progeny emergence. Kavallieratos et al. (2009) stated that the rates of 0.5 and $1.0 \mathrm{mg} \mathrm{kg}^{-1}$ prevented progeny emergence of $R$. dominica in wheat and corn. 
Table 2 Mortality rates of Rhyzopertha dominica after 7, 14, and 21 days of exposure to 5 grain species treated with abamectin

\begin{tabular}{|c|c|c|c|c|c|c|}
\hline \multirow[t]{2}{*}{ Insecticide } & \multirow{2}{*}{$\begin{array}{l}\text { Rate } \\
\left(\mathrm{g} \mathrm{kg}^{-1}\right)\end{array}$} & \multicolumn{5}{|c|}{ Mean mortality $(\% \pm \mathrm{SE})$ after exposure to 5 grain species } \\
\hline & & Wheat & Barley & Rye & Oats & Triticale \\
\hline \multicolumn{7}{|c|}{ After 7 days of exposure } \\
\hline \multirow[t]{3}{*}{ Abamectin } & 0.25 & $19.0 \pm 0.3 b^{*}$ & $6.5 \pm 0.2 b$ & $6.5 \pm 0.3 b$ & $26.5 \pm 0.3 a$ & $12.0 \pm 0.2 b$ \\
\hline & 0.5 & $22.0 \pm 0.3 b$ & $23.5 \pm 0.2 a$ & $7.5 \pm 0.3 b$ & $24.0 \pm 0.2 \mathrm{a}$ & $14.5 \pm 0.2 b$ \\
\hline & 1.0 & $56.5 \pm 0.3 a$ & $30.5 \pm 0.3 a$ & $27.5 \pm 0.3 a$ & $28.5 \pm 0.3 a$ & $26.5 \pm 0.2 \mathrm{a}$ \\
\hline Infested sample & 0 & $2.0 \pm 0.1 \mathrm{C}$ & $1.0 \pm 0.1 b$ & $2.0 \pm 0.1 b$ & $1.0 \pm 0.1 b$ & $3.0 \pm 0.1 \mathrm{c}$ \\
\hline$F$ & & 52.19 & 22.68 & 14.95 & 22.30 & 32.61 \\
\hline$P$ & & $<0.05$ & $<0.05$ & $<0.05$ & $<0.05$ & $<0.05$ \\
\hline \multicolumn{7}{|c|}{ After 14 days of exposure } \\
\hline \multirow[t]{3}{*}{ Abamectin } & 0.25 & $68.5 \pm 0.4 b$ & $54.0 \pm 0.4 b$ & $61.0 \pm 0.4 a$ & $87.5 \pm 0.3 a$ & $63.5 \pm 0.2 b$ \\
\hline & 0.5 & $67.0 \pm 0.4 b$ & $58.5 \pm 0.3 b$ & $66.5 \pm 0.3 a$ & $89.0 \pm 0.2 a$ & $61.0 \pm 0.3 b$ \\
\hline & 1.0 & $85.0 \pm 0.2 \mathrm{a}$ & $78.50 \pm 0.4 a$ & $81.0 \pm 0.3 a$ & $96.5 \pm 0.2 a$ & $79.0 \pm 0.3 a$ \\
\hline Infested sample & 0 & $2.0 \pm 0.1 c$ & $1.0 \pm 0.1 c$ & $2.0 \pm 0.1 b$ & $1.0 \pm 0.1 b$ & $3.0 \pm 0.1 c$ \\
\hline F & & 113.21 & 27.89 & 25.41 & 41.96 & 36.76 \\
\hline$P$ & & $<0.05$ & $<0.05$ & $<0.05$ & $<0.05$ & $<0.05$ \\
\hline \multicolumn{7}{|c|}{ After 21 days of exposure } \\
\hline \multirow[t]{3}{*}{ Abamectin } & 0.25 & $100.0 \pm 0.0 \mathrm{a}$ & $99.0 \pm 0.1 a$ & $98.5 \pm 0.2 \mathrm{a}$ & $99.5 \pm 0.1 a$ & $96.5 \pm 0.2 \mathrm{a}$ \\
\hline & 0.5 & $100.0 \pm 0.0 \mathrm{a}$ & $100.0 \pm 0.0 a$ & $99.0 \pm 0.1 \mathrm{a}$ & $100.0 \pm 0.0 \mathrm{a}$ & $99.0 \pm 0.1 a$ \\
\hline & 1.0 & $100.0 \pm 0.0 \mathrm{a}$ & $100.0 \pm 0.0 a$ & $100.0 \pm 0.0 \mathrm{a}$ & $100.0 \pm 0.0 \mathrm{a}$ & $100.0 \pm 0.0 \mathrm{a}$ \\
\hline Infested sample & 0 & $2.0 \pm 0.1 b$ & $1.0 \pm 0.1 b$ & $3.0 \pm 0.1 b$ & $1.0 \pm 0.1 b$ & $3.0 \pm 0.1 b$ \\
\hline$F$ & & 53.66 & 49.71 & 43.55 & 51.10 & 41.63 \\
\hline$P$ & & $<0.05$ & $<0.05$ & $<0.05$ & $<0.05$ & $<0.05$ \\
\hline
\end{tabular}

*For each exposure period separately, means within columns followed by the same letter are not significantly different. Tukey-Kramer (HSD) test at $P>0.05$; in all cases $\mathrm{df}=8,70 ; P<0.05$

These authors noted progeny in 2 examined grain types only at low rates of abamectin $\left(0.01\right.$ and $\left.0.1 \mathrm{mg} \mathrm{kg}^{-1}\right)$.

As for the damage in infested grains in the untreated infested triticale sample, the highest mass of damaged grain was recorded $(10.26 \mathrm{~g})$. In the triticale sample treated with 0.5 and $1.0 \mathrm{mg} \mathrm{kg}^{-1}$ of abamectin, the mass was the lowest $(0.11-0.11 \mathrm{~g})$ than in other grain species (0.44-0.50 g, $0.18-0.32 \mathrm{~g}, 0.24-0.36 \mathrm{~g}, 0.14-0.44 \mathrm{~g}$, respectively). In samples treated with abamectin, at the rates of 0.25 and $0.50 \mathrm{mg} \mathrm{kg}^{-1}$, dust as a nus-product of feeding of $R$. dominica larvae and imago was present as an amount of $0.01 \mathrm{~g}$ (Table 4).

The amount of damaged grain and the dust, as a nusproduct of feeding of $R$. dominica larvae and imago, can be attributed to the slowest action of this natural insecticide since pest mortality in the 1st week was not satisfactory. Slowing efficiency is a minus in the use of abamectin, but this is common for all insecticides of natural origin (spinosad, diatomaceous earth, etc.). During the evaluation of the efficacy of applied natural insecticides (diatomaceous earth), Perišić et al. (2018a) recorded the same correlation between the efficacy of applied insecticide and the mass of the dust. The measured amounts were significantly lower than the untreated infested sample, which represented a positive aspect of abamectin application.

The application of abamectin contributed to a significant difference in moisture content than the control sample (untreated and un-infested sample). The smallest differences were recorded in oats (Table 5). Significant

Table 3 Progeny emergence (adults/val) and reduction of Rhyzopertha dominica in 5 grain species treated with abamectin

\begin{tabular}{|c|c|c|c|c|c|c|}
\hline \multirow[t]{2}{*}{ Insecticide } & \multirow{2}{*}{$\begin{array}{l}\text { Rate } \\
\left(\mathrm{g} \mathrm{kg}^{-1}\right)\end{array}$} & \multicolumn{5}{|c|}{ Mean mortality (adults/val) after exposure } \\
\hline & & Wheat & Barley & Rye & Oats & Triticale \\
\hline \multirow[t]{3}{*}{ Abamectin } & 0.25 & 0 & 0 & 0 & 0 & 0 \\
\hline & 0.5 & 0 & 0 & 0 & 0 & 0 \\
\hline & 1.0 & 0 & 0 & 0 & 0 & 0 \\
\hline Infested sample & 0 & $128.5 \pm 1.0$ & $82.1 \pm 0.8$ & $177.1 \pm 0.8$ & $36.4 \pm 0.3$ & $432.5 \pm 0.8$ \\
\hline
\end{tabular}


Table 4 Amount of insect-damaged grains and dockage $(\mathrm{g} \pm \mathrm{SE}), 10$ weeks after the treatment of 5 grain species with abamectin

\begin{tabular}{|c|c|c|c|c|c|c|}
\hline \multirow[t]{2}{*}{ Insecticide } & \multirow{2}{*}{$\begin{array}{l}\text { Rate } \\
\left(\mathbf{g ~ k g}^{-1}\right)\end{array}$} & \multicolumn{5}{|c|}{ Damaged grains and dockage $(\mathrm{g} \pm \mathrm{SE})$} \\
\hline & & Wheat & Barley & Rye & Oats & Triticale \\
\hline \multicolumn{7}{|l|}{ Damaged grains } \\
\hline \multirow[t]{3}{*}{ Abamectin } & 0.25 & $0.58 \pm 0.0 \mathrm{a}$ & $0.15 \pm 0.0 \mathrm{a}$ & $0.28 \pm 0.0 \mathrm{a}$ & $0.22 \pm 0.0 \mathrm{ab}$ & $0.24 \pm 0.0 \mathrm{a}$ \\
\hline & 0.5 & $0.44 \pm 0.1 \mathrm{a}$ & $0.18 \pm 0.0 \mathrm{a}$ & $0.24 \pm 0.0 \mathrm{a}$ & $0.41 \pm 0.1 \mathrm{ab}$ & $0.11 \pm 0.0 a$ \\
\hline & 1.0 & $0.50 \pm 0.1 a$ & $0.32 \pm 0.1 \mathrm{a}$ & $0.36 \pm 0.1 \mathrm{a}$ & $0.14 \pm 0.0 \mathrm{a}$ & $0.11 \pm 0.0 \mathrm{a}$ \\
\hline Infested sample & 0 & $6.83 \pm 0.3 b$ & $3.04 \pm 0.2 b$ & $6.85 \pm 0.2 b$ & $0.44 \pm 0.1 b$ & $10.26 \pm 0.2 b$ \\
\hline F & & 11.00 & 11.95 & 29.99 & 3.51 & 35.93 \\
\hline P & & $<0.05$ & $<0.05$ & $<0.05$ & $<0.05$ & $<0.05$ \\
\hline \multicolumn{7}{|l|}{ Dockage } \\
\hline \multirow[t]{3}{*}{ Abamectin } & 0.25 & $0.01 \pm 0.0 \mathrm{a}$ & $0.01 \pm 0.0 \mathrm{a}$ & $0.01 \pm 0.0 \mathrm{a}$ & $0.01 \pm 0.0 \mathrm{a}$ & $0.01 \pm 0.0 \mathrm{a}$ \\
\hline & 0.5 & $0.01 \pm 0.0 \mathrm{a}$ & $0.01 \pm 0.0 \mathrm{a}$ & $0.01 \pm 0.0 \mathrm{a}$ & $0.01 \pm 0.0 \mathrm{a}$ & $0.01 \pm 0.0 \mathrm{a}$ \\
\hline & 1.0 & $0.00 a$ & $0.00 \mathrm{a}$ & $0.00 a$ & $0.00 a$ & $0.00 a$ \\
\hline Infested sample & 0 & $2.04 \pm 0.1 b$ & $1.05 \pm 0.1 b$ & $3.80 \pm 0.2 b$ & $0.27 \pm 0.0 b$ & $5.20 \pm 0.2 b$ \\
\hline F & & 21.81 & 25.12 & 41.81 & 20.21 & 40.89 \\
\hline P & & $<0.05$ & $<0.05$ & $<0.05$ & $<0.05$ & $<0.05$ \\
\hline
\end{tabular}

*For each parameter separately, means within columns followed by the same letter are not significantly different; Tukey-Kramer (HSD) test at $P>0.05$; in all cases, $\mathrm{df}=8,70 ; P<0.05$

Table 5 Moisture, protein, and ash contents in 5 grain species treated with abamectin after Rhyzopertha dominica progeny count

\begin{tabular}{|c|c|c|c|c|c|c|}
\hline \multirow[t]{2}{*}{ Insecticide } & \multirow{2}{*}{$\begin{array}{l}\text { Rate } \\
\left(\mathrm{g} \mathrm{kg}^{-1}\right)\end{array}$} & \multicolumn{5}{|c|}{ Moisture, protein, and ash contents $(\% \pm \mathrm{SE})$} \\
\hline & & Wheat & Barley & Rye & Oats & Triticale \\
\hline \multicolumn{7}{|l|}{ Moisture content $\%$} \\
\hline \multirow[t]{3}{*}{ Abamectin } & 0.25 & $13.11 \pm 0.02 b$ & $12.90 \pm 0.01 d$ & $12.90 \pm 0.03 c$ & $11.59 \pm 0.01 c$ & $12.79 \pm 0.03 c$ \\
\hline & 0.5 & $13.01 \pm 0.02 b$ & $12.69 \pm 0.02 c$ & $12.81 \pm 0.02 c$ & $11.80 \pm 0.01 d$ & $12.37 \pm 0.03 b$ \\
\hline & 1.0 & $13.00 \pm 0.01 b$ & $12.20 \pm 0.01 b$ & $12.30 \pm 0.03 b$ & $11.19 \pm 0.01 b$ & $12.70 \pm 0.02 \mathrm{c}$ \\
\hline Infested sample & & $14.61 \pm 0.05 c$ & $13.41 \pm 0.02 \mathrm{e}$ & $13.60 \pm 0.06 d$ & $11.81 \pm 0.02 d$ & $14.42 \pm 0.07 d$ \\
\hline Control & & $12.41 \pm 0.01 a$ & $11.81 \pm 0.01 a$ & $11.71 \pm 0.01 a$ & $11.00 \pm 0.01 a$ & $11.8 \pm 0.01 \mathrm{a}$ \\
\hline$F$ & & 181 & 112.4 & 49.4 & 22.7 & 275.7 \\
\hline P & & $>0.05$ & $>0.05$ & $>0.05$ & $>0.05$ & $>0.05$ \\
\hline \multicolumn{7}{|l|}{ Protein content $\%$} \\
\hline \multirow[t]{3}{*}{ Abamectin } & 0.25 & $13.12 \pm 0.02 b$ & $12.02 \pm 0.04 a$ & $15.76 \pm 0.02 a$ & $13.29 \pm 0.02 b c$ & $12.29 \pm 0.01 b$ \\
\hline & 0.5 & $13.15 \pm 0.02 b$ & $12.00 \pm 0.03 a$ & $15.75 \pm 0.02 a$ & $13.29 \pm 0.02 b c$ & $12.28 \pm 0.02 b$ \\
\hline & 1.0 & $13.15 \pm 0.01 b$ & $12.02 \pm 0.04 a$ & $15.75 \pm 0.02 a$ & $13.30 \pm 0.02 \mathrm{ab}$ & $12.30 \pm 0.01 \mathrm{ab}$ \\
\hline Infested sample & & $12.47 \pm 0.02 \mathrm{c}$ & $11.72 \pm 0.02 b$ & $15.54 \pm 0.05 b$ & $13.28 \pm 0.02 c$ & $10.72 \pm 0.05 c$ \\
\hline Control & & $13.22 \pm 0.01 a$ & $12.05 \pm 0.02 a$ & $15.81 \pm 0.02 \mathrm{a}$ & $13.31 \pm 0.01 a$ & $12.32 \pm 0.01 a$ \\
\hline$F$ & & 69 & 19 & 305 & 4 & 562 \\
\hline P & & $>0.05$ & $>0.05$ & $>0.05$ & 0.0012 & $>0.05$ \\
\hline \multicolumn{7}{|l|}{ Ash content $\%$} \\
\hline \multirow[t]{3}{*}{ Abamectin } & 0.25 & $1.74 \pm 0.03 a$ & $2.33 \pm 0.02 a$ & $1.96 \pm 0.03 b$ & $3.38 \pm 0.06 a$ & $2.31 \pm 0.06 a$ \\
\hline & 0.5 & $1.74 \pm 0.04 a$ & $2.33 \pm 0.02 a$ & $1.94 \pm 0.03 a b$ & $3.36 \pm 0.04 a$ & $2.29 \pm 0.02 a$ \\
\hline & 1.0 & $1.73 \pm 0.04 a$ & $2.32 \pm 0.01 a$ & $1.95 \pm 0.03 a b$ & $3.38 \pm 0.06 a$ & $2.27 \pm 0.02 a$ \\
\hline Infested sample & & $1.83 \pm 0.04 b$ & $2.44 \pm 0.04 a$ & $2.09 \pm 0.03 c$ & $3.40 \pm 0.03 a$ & $2.82 \pm 0.4 b$ \\
\hline Control & & $1.72 \pm 0.05 a$ & $2.34 \pm 0.05 a$ & $1.91 \pm 0.06 a b$ & $3.38 \pm 0.03 a$ & $2.25 \pm 0.05 a$ \\
\hline$F$ & & 5.03 & 0.79 & 26.0 & 0.9 & 144.3 \\
\hline$P$ & & $>0.05$ & 0.596 & $>0.05$ & 0.52 & $>0.05$ \\
\hline
\end{tabular}

*For each parameter separately, means within columns followed by the same letter are not significantly different; Tukey-Kramer (HSD) test $P>0.05$; in all cases, $\mathrm{df}=10,76 ; P<0.05$ 
differences were recorded between infested and other species of samples. Moisture contents and weight of damaged grain were compared, using the linear correlation analysis with Pearson's coefficient $(P<0.05, N=$ 56) and with significant positive correlations, detected for wheat $(r=0.722, P<0.05)$ and triticale $(r=$ $0.800, P<0.05)$. The less positive correlation was of barley $(r=0.598, P<0.05)$ and rye $(r=0.675, P<$ $0.05)$, while in oats the correlation between these 2 values $(r=-0.720, P=0.598)$ was not detected. A significant difference in the total protein content in examined grain species was recorded in infested samples. The application of the examined insecticide did not change significantly the protein content in comparison to control (Table 5). The comparison of protein content to the mass of damaged kernels, analyzed by linear correlation with Pearson's coefficient for $P<0.05, N=56$, revealed the existence of a significant negative correlation for rye $(r=$ 0.727; $P<0.05)$ and triticale $(r=-0.768, P<0.05)$ and a low negative correlation for wheat $(r=-0.566, P<0.05)$ and barley $(r=-0.651, P<0.05)$, while the correlation does not exist between the 2 values of oats $(r=0.274, P=0.087)$.

Abamectin application did not affect variation in the ash content of the examined grain species. Exception represented in the abamectin application in rye, with increased ash content for $0.05,0.03$, and $0.04 \%$ than the control. The ash content of the infested sample increased in a greater extent $(0.18 \%)$. In infested samples of wheat, rye, and triticale, significantly high ash contents were recorded than the control and the samples treated with insecticide. In barley and oats, significant variation in this parameter was not found. The comparison of ash content to the mass of damaged kernels, analyzed by linear correlation with Pearson's coefficient for $P<0.05, N=56$, revealed the existence of significant positive correlations of wheat $(r=0.662, P<0.05)$, rye $(r=0.701, P<0.05)$, and triticale $(r=0.824, P<0.05)$, while there was no correlation between the 2 values for barley and oats $(r=0.189$, $P=0.242$ and $r=0.170, P=0.293$ ).

Treated samples showed an increase in the moisture content. Technological grain properties (protein and ash contents) did not change in treated samples, which is a positive aspect of the use of abamectin. There are no appropriate references about the impact of abamectin application on the chemical properties of grains. The greatest extent of changes in moisture, protein, and ash contents were recorded in the untreated, infested sample and samples with $0.25 \mathrm{mg} \mathrm{kg}^{-1}$ abamectin, as a consequence of the greatest presence of $R$. dominica, proved by Pearson's coefficient of linear correlation. Since $R$. dominica is feeding mostly on endosperm and a germ (Edde 2012), a change in these properties in untreated, infested grain samples as a consequence of infestation and the highest level of grain damage could be expected. These results are in agreement with that reported by Ozkaya et al. (2009), Bodroža-Solarov et al. (2012), and Perišić et al. (2018b) who determined changes in technological properties because of the presence of $R$. dominica.

\section{Conclusions}

Technological grain properties (protein and ash contents) did not change in the treated samples, which is a positive aspect of the use of abamectin. High rates of $R$. dominica mortality were recorded after 21 days of exposure where a total prevention of progeny emergence occurred.

\section{Abbreviation \\ a.s.: Active substance}

\section{Acknowledgements}

This work was supported by the Ministry of Education, Science and Technological Development of the Republic of Serbia (Agreement No. 45103-68/2020-14/200122). We thank the Editor and two anonymous reviewers for evaluation, comments, and improving the manuscript.

\section{Authors' contributions}

In this research, all authors contributed effectively. VMP designed and achieved experiments and wrote the manuscript; DP, FV, VR, and VDP carried out the experiments; GA and PK analyzed the data, supervised the project, and revised the manuscript. All authors have read and approved the manuscript.

\section{Funding}

Ministry of Education, Science and Technological Development of the Republic of Serbia (Agreement No. 451-03-68/2020-14/200122). The founder financially supported part of the experimental research for FV and DP as part of the preparation of their doctoral dissertations.

\section{Availability of data and materials}

The data and material of this manuscript are available on reasonable request.

Ethics approval and consent to participate

We agree to all concerned regulations. This article does not contain any studies with human participants or animals or human tissue.

Consent for publication

Not applicable

\section{Competing interests}

The authors declare that they have no competing interests.

\section{Author details}

${ }^{1}$ Faculty of Agriculture, University of Niš, Kosančićeva 4, Kruševac 37000, Serbia. ${ }^{2}$ Center of Small Grains, Save Kovačevića 31, Kragujevac 34000, Serbia. ${ }^{3}$ Department of Biology and Ecology, Faculty of Science, University of Kragujevac, Radoja Domanovića 12, Kragujevac 34000, Serbia. ${ }^{4}$ Laboratory of Applied Entomology, Institute of Pesticides and Environmental protection, Banatska 31b, Belgrade 11080, Serbia.

Received: 24 April 2020 Accepted: 31 August 2020

Published online: 15 September 2020

\section{References}

Athanassiou CG, Kavallieratos NG (2005) Insecticidal effect and adherence of PyriSec in different grain commodities. Crop Prot 27:703-710. https://doi.org/ 10.1016/j.cropro.2004.12.004

Beeman R, Speirs W (1984) Toxicity, persistence and 284 antagonism of avermectin B1 against stored-product insects. In: Proceedings of the $3^{\text {rd }}$ 
International Working Conference on Stored Product Entomology, Manhattan, USA, 23-28 October 1984.

Bodroža-Solarov M, Kljajić P, Andrić G, Filipčev B, Dokić Lj (2012) Quality parameters of wheat grain and flour as influenced by treatments with natural zeolite and diatomaceous earth formulations, grain infestation status and endosperm 306 vitreousness. J Stored Prod Res 51:61-307 68. https://doi. org/10.1016/j.jppr.2012.07.001

Edde P (2012) A review of the biology and control of Rhyzopertha dominica (F.) the lesser grain borer. J Stored Prod Res 48:1-18. https://doi.org/10.1016/j. jspr.2011.08.007

International association for cereal science and technology (1976) Determination of the moisture content of cereals and cereal products (practical method). ICC standard method No. 110/1. International association for cereal science and technology, Vienna, Austria.

International association for cereal science and technology (1990) Determination of ash in cereals and cereal products. ICC standard method No. 104/1. International association for cereal science and technology Vienna, Austria.

International association for cereal science and technology (1994) Determination of crude protein in cereals and cereal products for food and for feed. ICC standard method No. 105/2. International association for cereal science and technology, Vienna, Austria.

Kavallieratos N, Athanassiou C, Vayias B, Mihail B, Tomanović Ž (2009) Insecticidal efficacy of abamectin against three stored-product insect pests: influence of dose rate, temperature, commodity and exposure interval. J Econ Entomol 102:1352-1360. https://doi.org/10.1603/029.102.0363

Kim SB, Goodfellow M (2002) Streptomyces avermitilis sp. nov. nom. rev., a taxonomic home for the avermectin-producing streptomycetes. Int I Syst Evol Microbiol 52:2011-2014. https://doi.org/10.1099/00207713-52-6-2011

OEPP/EPPO - European and Mediterranean Plant Protection Organization (2004a) Admixture of plant protection products to stored plant products to control insects and mites, PP 1/203(1). In: Efficacy evaluation of insecticides and Acaricides EPPO Standards PP1, sec. ed.; European and Mediterranean Plant Protection Organization, Paris, France.

OEPP/EPPO - European and Mediterranean Plant Protection Organization (2004b) Laboratory testing of plant protection products against insect and mite pests of stored plant products, PP 1/204(1). In: Efficacy evaluation of insecticides and Acaricides EPPO Standards PP1, sec. ed.

Ozkaya H, Ozkaya B, Colakoglu A (2009) Technological properties of a variety of soft and hard bread wheat infested by Rhyzopertha dominica (F.) and Tribolium confusum du Val. J Food Agric Environ 7(3-4):166-172. https://doi. org/10.1603/EC12391

Perišić V, Hadnađev M, Perišić V, Vukajlović F, Dapčević-Hadnađev T, Luković K, Đekić V (2018a) Technological quality of wheat infested with Rhyzopertha dominica F. (Coleoptera: Bostrichidae). Advan technolog 7:35-40 Available at: https://scindeksclanci.ceon.rs/data/pdf/2406-2979/2018/2406-29791801035P. pdf

Perišić V, Vuković S, Perišić V, Pešić S, Vukajlović F, Andrić G, Kljajić P (2018b) Insecticidal activity of three diatomaceous earths on lesser grain borer, Rhyzopertha dominica F., and their effects on wheat, barley, rye, oats and triticale grain properties. J Stored Prod Res 75:38-46. https://doi.org/10.1016/ j.jspr.2017.11.006

Subramanyam BH, Roesli R (2000) Inert dusts. In: Subramanyam BH, Hagstrum DW (eds) Alternatives to pesticides in stored-product IPM. Kluwer Academic Publishers, Boston, MA, pp 321-380 ISBN 978-1-4615-4353-4

\section{Publisher's Note}

Springer Nature remains neutral with regard to jurisdictional claims in published maps and institutional affiliations.

\section{Submit your manuscript to a SpringerOpen ${ }^{\circ}$ journal and benefit from:}

- Convenient online submission

- Rigorous peer review

- Open access: articles freely available online

- High visibility within the field

- Retaining the copyright to your article

Submit your next manuscript at $\boldsymbol{\nabla}$ springeropen.com 